\title{
International Society for the Advancement of Kinanthropometry (ISAK) Global: international accreditation scheme of the competent anthropometrist
}

\section{Sociedade Internacional para o Avanço da Cineantropometria (ISAK) Global: esquema internacional de acreditação do antropometrista competente}

Vladimir Schuindt da Silva ${ }^{\top}$

(iD http://orcid.org/0000-0002-6010-5002

Maria Filomena Soares Vieira²

(D) http://orcid.org/0000-0002-7547-5487

Abstract - The anthropometric assessment of a person or population is used by professionals from different areas (health, sports, education, ergonomics, engineering), and the quality of the measures obtained by them determines the success of their interventions. This point of view aims to underline the importance of training these professionals through The International Anthropometry Accreditation Scheme (IAAS) implemented by The International Society for the Advancement of Kinanthropometry (ISAK), which aims to create and maintain an international network of professionals updated continuously from the practical and scientific point of view in the anthropometric measurement of excellence. We describe the four-level hierarchical structure of IAAS, which is guided by the rules defined in the ISAK Handbook and the anthropometric procedures described in the ISAK manuals, as well as the importance and functionality of the ISAK website. It is suggested that an ISAK mobile app be developed to, among other things, facilitate communication among its members, streamline data management of accreditation courses and increase the organization's international projection. Key words: Anthropometry; Body weights and measures; Certification; Kinanthropometry

Resumo - A avaliação antropométrica, de uma pessoa ou população, é utilizada por profissionais de diferentes áreas (saúde, desporto, educaçẫo, ergonomia, engenharia), sendo a qualidade das medidas por eles obtida determinante para o sucesso das suas intervençōes. O objetivo deste ponto de vista é salientar a importância da formação destes profissionais através do Esquema Internacional de Acreditação em Antropometria/ International Antbropometry Accreditation Scheme (IAAS) implementado pela Sociedade Internacional para o Avanço da Cineantropometrial International Society for the Advancement of Kinanthropometry (ISAK), entidade que tem o propósito de criar e manter uma rede internacional de profissionais constantemente atualizados do ponto de vista prático e cientifico na medição antropométrica de excelência. Descrevemos a estrutura hierárquica de quatro níveis do IAAS, que se orienta pelas regras definidas no Handbook ISAK e pelos procedimentos antropométricos descritos nos manuais ISAK, e ainda a importância e funcionalidades do site da ISAK. Sugere-se o desenvolvimento de um aplicativo móvel da ISAK para, entre outras coisas, facilitar a comunicação entre seus membros, otimizar o gerenciamento de dados dos cursos de acreditação e aumentar a projeção internacional da organização.

Palavras-chave: Antropometria; Certificação; Cineantropometria; Pesos e medidas corporais

1 Benjamin Constant Institute. Rio de Janeiro, RJ. Brazil.

2 CIPER (Centro Interdisciplinar de Estudo da Performance Humana). Laboratório de Biomecânica e Morfologia Funcional. Faculdade de Motricidade Humana. Universidade de Lisboa. Cruz Quebrada. Portugal.

Received: December 07, 2019 Accepted: January 17, 2020

How to cite this article Silva VS, Vieira F. International Society for the Advancement of Kinanthropometry (ISAK) Global: international accreditation scheme of the competent anthropometrist. Rev Bras Cineantropom Desempenho Hum 2020, 22:e70517. D0I: http://dx.doi. org/10.1590/1980-0037.2020v22e70517.

Copyright: This work is licensed under a Creative Commons Attribution 4.0 International License. 


\section{INTRODUCTION}

In 1978, the International Council for Sport Science and Physical Education (ICSSPE) met in Brazil and created the International Working Group on Kinanthropometry (IWGK), which propelled Kinanthropometry as a scientific discipline that applies anthropometry to the study of movement, until the establishment of the International Society for the Advancement of Kinanthropometry (ISAK), July 20, 1986 in Glasgow, Scotland. ISAK aims to create and maintain an international network of professionals who are regularly updated from a practical and scientific point of view in the anthropometric measurement of excellence ${ }^{1,2}$.

The anthropometric measurement procedures proposed by both IWGK and ISAK have been published in books or manuals, thus contributing to their wide dissemination. Examples are the Anthropometric Standardization Reference $\mathrm{Manual}^{3}$, which combines the procedures defined in 1985 by IGKW, namely, Anthropometrica ${ }^{4}$, with the first standards proposed by ISAK, and the different editions of the International Standards for Anthropometric Assessment ${ }^{1,2,5-7}$.

ISAK is managed by a Council, currently chaired by Prof. Dr. Michael Marfell-Jones, with its secretary Prof. Dr. Francisco Esparza-Ros, both level 4 criterion anthropometrists, assisted by the Standards and Accreditation Working Group, the Special Projects and Archive Group, and the Grant Committee, besides the support of the Editor, Prof. Fernando Ferreyro Bravo, from the Kinanthreport newsletter.

It has an official website ${ }^{8}$ that centralizes all ISAK information and has a restricted area, with some features, for certified anthropometrists, over 30,000 professionals in 86 countries who follow the international scheme of anthropometric measurement techniques guided by the ISAK Manual ${ }^{1,2}$ and the ISAK Handbook ${ }^{9}$.

The improved anthropometric assessment standards, based on already established methodologies, and the development of an international accreditation scheme, based on the concept of a four-tier hierarchy, with high rigor and quality maintenance, are ISAK's differentials, recognized worldwide, as the management system of the ISAK Secretariat has been certified by International Organization for Standardization (ISO) 9001 through the Bureau Veritas Certification. Thus, this point of view aims to highlight the magnitude of ISAK's global organizational structure.

\section{ACCREDITATION SCHEME}

The International Anthropometry Accreditation Scheme (IAAS) has three related components: 1) Definition, rules, and regulations; 2) ISAK Manual $^{1,2}$; and 3) ISAK Handbook ${ }^{9}$, and is based on the concept of a fourtier hierarchy (Table 1) with the highest quality standards.

The level 1 anthropometrist (Technician - Restricted Profile), comprises a narrow measurement profile and was designed for most ISAK-accredited 
anthropometrists who have a low ongoing requirement for more than basic and skinfold measurement. The level 2 anthropometrist (Technician Full Profile), includes a complete measurement profile and was designed for anthropometrists to show adequate accuracy over a broader range of measurements and a broad understanding of anthropometric theory and its interpretation. The level 3 anthropometrist (Instructor), is designed only for anthropometrists who wish to engage in the training and accreditation of level 1 and 2 anthropometrists to increase the availability of courses to a more significant number of applicants worldwide. Also, the Grant Committee has approved a training grant project to support the development of anthropometry in countries with a low number of ISAK anthropometrists to assist promising level 2 anthropometrists from countries with no level 4 instructors and few level 3 instructors to earn this accreditation, and thus increase the offer of level 1 and 2 courses in their country ${ }^{10}$. The level 4 anthropometrist (Criterion), requires a set of attributes established by ISAK and is reserved for a relatively small group of internationally recognized anthropometrists who have the responsibility to train and examine level 3 anthropometrists, as well as the right to train and examine two other levels9.

The validity of ISAK certificates expires every four years and four months (level 1) or six months (level 2, 34 ), making it optional to revalidate accreditation (Re-accreditation), with mandatory compliance with rules established by the organization ${ }^{1,2,8}$.

ISAK courses must be approved by the Standards and Accreditation Working Group, at least two months before the onset of the course, and must be registered on the official website ${ }^{7}$ by the course instructor, who must follow ISAK's anthropometric accreditation scheme to ensure standardization and that all graduates have the same level of knowledge and skills ${ }^{1,2}$. In other words, the courses have a minimum duration for each level (Table 2) and always include a practical exam, where each candidate

Table 1. International anthropometry accreditation scheme of the ISAK.

\begin{tabular}{|c|c|c|c|c|c|c|c|c|c|}
\hline \multirow{4}{*}{ Level } & \multirow{4}{*}{$\mathrm{L} / \mathrm{M}$} & \multirow{4}{*}{ Instructor } & \multirow{4}{*}{ P-r } & \multicolumn{6}{|c|}{$\%$ Technical Error of Measurement } \\
\hline & & & & \multicolumn{4}{|c|}{ Intra-tester } & \multirow{2}{*}{\multicolumn{2}{|c|}{$\begin{array}{c}\text { Inter-tester } \\
\text { W-C }\end{array}$}} \\
\hline & & & & \multicolumn{2}{|c|}{ W-C } & \multicolumn{2}{|c|}{$P-C$} & & \\
\hline & & & & $S$ & 0 & $S$ & 0 & $S$ & 0 \\
\hline 1 & $15 / 21$ & No & None & 10.0 & 2.0 & 7.5 & 1.5 & 12.5 & 2.5 \\
\hline 2 & $22 / 43$ & No & L1 & 7.5 & 1.5 & 5 & 1 & 10 & 2 \\
\hline 3 & $22 / 43$ & Yes & L2 & 7.5 & 1.5 & 5 & 1 & 10 & 2 \\
\hline 4 & $22 / 43$ & Yes & L3 & 7.5 & 1.5 & 5 & 1 & 10 & 2 \\
\hline
\end{tabular}

Note. ISAK: International Society for the Advancement of Kinanthropometry. L: Landmarking. M: measurements. P-r: pre-requisites. W-C: within-course. P-C: post-course profiles. S: skinfolds. 0: other measurements.

Table 2. Duration of the courses of the International Society for the Advancement of Kinanthropometry.

\begin{tabular}{cccccc}
\hline \multirow{2}{*}{ Level } & \multirow{2}{*}{ Days } & \multicolumn{2}{c}{ Course workload hours } & \multirow{2}{*}{ Post-course workload hours } & Individual work hours \\
\cline { 3 - 4 } & & Theory & Practice & & 16 \\
\hline 1 & 3 & 6 & 18 & 20 & 20 \\
3 & 4 & 10 & 22 & 20 & 34 \\
\hline
\end{tabular}


must measure three subjects and obtain in each of them, sequentially, two or three repetitions of 10 anthropometric measurements.

Worth noting is that it is not permitted to offer courses where the ISAK certificate is optional and if ISAK accreditation and membership are optional in a course. This cannot be considered official, and the use of the ISAK logo for its promotion is not authorized. Also, the instructor is always obliged to grade the practical exam, and graduates must submit 20 anthropometric assessments to obtain the certificate within four and six months from the day of the exam for level 1 and the other levels, respectively.

Graduates are advised to indicate in scientific productions, as well as in professional practice, the estimated Technical Error of Measurement (TEM) intra and inter-tester errors and calculated coefficient of reliability $^{11}$, besides declaring the anthropometrist level within ISAK, as quality indicators of anthropometric measurement ${ }^{9}$.

\section{ISAK MANUAL}

The ISAK Manual ${ }^{1,2}$ is published in Spanish and English, languages officially used by the organization, and contributes to ensuring the quality of the courses and the uniformity of the organizational aspects. The delivery of a hard copy to each person is mandatory in the courses.

Unlike the previous ones ${ }^{5-7}$ the new edition has books specific to restricted (level 1) and full (level 2, 3 and 4, without exception) profiles, and has been available since April 12, 2019 through authorized distributors on five continents, whose contacts are available through the ISAK office (info@isak.global) or the restricted area of website ${ }^{8}$ (teaching area).

The current edition contains, for all landmarking and measurements, a Quick Response (QR) Code for a video demonstration of the techniques established in the ISAK Manual1,2. This change is fundamental, on the one hand, to standardize the teaching techniques used by level 3 and 4 anthropometrists, and on the other, to facilitate the learning process for ISAK course participants. Additionally, there was a change in the measures included in the restricted and full profiles. Four new measures were included in the restricted profile: sitting height, arm span, thigh middle girth (in landmarking of the thigh skinfold), and bi-styloid breadth. The mid-trochanterion-tibiale laterale landmark was excluded, and the bimalleolar breadth was included in the full profile.

\section{WEBSITE: ISAK GLOBAL}

The website ${ }^{8}$ facilitates the identification of anthropometrists, the dissemination of courses and their organizational aspects, the world congress, held every two years, news, and other information. The current version contains a restricted area, with some features, for certified anthropometrists, such as: 1) Home; 2) Courses (search and records); 3) Teaching area (documents and videos); 4) Content of interes; plus, a message box and the possibility to enter profiles from three social networks. 


\section{FINAL COMMENTS}

ISAK has become a global network of thousands of professionals, engaged in scientific research or professional practice, interested in the excellence of anthropometric measurements, with an indication of TEM estimates and reliability in the population of interest.

The development of an ISAK mobile app with distribution to online mobile software stores (i.e., Google Play Store and Apple Store) is suggested to facilitate communication between its members, streamline data management of accreditation courses, provide a reporting, suggestions, criticism and praise channel, increase the international projection of the organization, and other information.

\section{COMPLIANCE WITH ETHICAL STANDARDS}

\section{Ethical approval}

This article did not use data collected from humans and represents a scientific opinion of literature. The article was written in accordance with standards set by the Declaration of Helsinki.

\section{Conflict of interest statement}

The authors have no conflict of interests to declare.

\section{Author Contributions}

Conception: VSS. Wrote the paper: VSS and MFSV.

\section{REFERENCES}

1. Esparza-Ros F, Vaquero-Cristóbal R, Marfell-Jones M. Protocolo internacional para la valoración antropométrica. Perfil Restrito. Murcia: International Society for the Advancement of Kinanthropometry - ISAK, 2019.

2. Esparza-Ros F, Vaquero-Cristóbal R, Marfell-Jones M. Protocolo internacional para la valoración antropométrica. Perfil Completo. Murcia: International Society for the Advancement of Kinanthropometry - ISAK, 2019.

3. Lohman TG, Roche AF, Martorell, R. Anthropometric standardization reference manual. Human Kinetics, Champaign, 1988.

4. Norton, K, Olds, T. Anthropometrica: a textbook of body measurement for sports and health courses. UNSW Press: Sydney, Australia, 1996.

5. International Society for the Advancement of Kinanthropometry (ISAK). International standards for anthropometric assessment. Underdale, SA, Australia, 2001.

6. Marfell-Jones, M, Olds, T, Stewart, A, Crater, JEL. International standards for anthropometric assessment. Potchefstroom, South Africa: International Society for the Advancement of Kinanthropometry - ISAK, 2006.

7. Stewart A, Marfell-Jones M, Olds T, Ridder H. International standards for anthropometric assessment. Lower Hutt, New Zealand: International Society for the Advancement of Kinanthropometry - ISAK, 2011.

8. International Society for the Advancement of Kinanthropometry/ISAK. Isak global. 2019; Available from: https://www.isak.global/Home/Index [2019 nov 17].

9. Marfell-Jones M, Esparza-Ros F, Vaquero-Cristóbal R. ISAK accreditation handbook. Murcia: International Society for the Advancement of Kinanthropometry - ISAK, 2019. 
10. International Society for the Advancement of Kinanthropometry/ISAK. KINANTHREPORT/ISAK NEWSLETTER: México. 2019;39:16 Available from: https://www.isak.global/Magazine/List [2020 jan 17].

11. Silva DAS, Pelegrini A, Pires-Neto CS, Vieira MFS, Petroski EL. O antropometrista na busca de dados mais confiáveis. Rev Bras Cineantropom Desempenho Hum 2011;13(1):82-5.

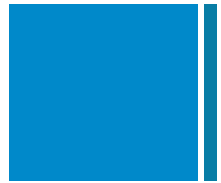

Corresponding author

Vladimir Schuindt da Silva

Pasteur Avenue, 350/ 368, Urca. Zip code: 22290-250

Rio de Janeiro, RJ, Brazil

E-mail: vladimirschuindt@hotmail.com 